\title{
STRATEGIC PRIORITIES OF GREEN COMPANIES IN INDONESIA
}

\author{
Siti Ridloah*, Nury Ariani Wulansari and Desti Ranihusna \\ Universitas Negeri Semarang, Indonesia
}

\begin{abstract}
This study aims to find out what strategic priorities that green companies need in Indonesia. Employing an innovative technique of Wordle, this paper utilized qualitative clustering through 'idea networking' to obtain the strategic priorities of the companies predicated the green industry in Indonesia. The results of the study reveal that the strategic priorities of green companies in Indonesia have several important points, namely: Excellence, Sustainability, Ecofriendly, CSR, Value Creation, Customer Focus, and Efficient. These findings provide valuable information on how green industries meeting environmental demands.
\end{abstract}

Keywords: Green companies, Idea networking, Strategic priorities, Wordle, Sustainabilities

Submitted: 21 January 2020; Revised: 05 March 2020; Accepted: 9 March 2020

* Corresponding Author: siti.ridloah@mail.unnes.ac.id

DOI: $10.24252 /$ minds.v7i1.12187

ISSN-E: 2597-6990 


\section{INTRODUCTION}

The industrial sector is a sector that plays a vital role in the economy of a country through the provision of employment and the use of natural resources. The industrial sector utilizes natural resources that are processed to increase added value. The more limited the availability of natural resources and the carrying capacity of the environment, then demanding industrial development must also pay attention to the protection of environmental quality and a sustainable ecosystem.

The green industry is firms considered to be environmental-friendly. According to the Ministry of Industry (2014), the green industry is an industry which in its production process applies efficiency and effectiveness efforts in the sustainable use of resources. Along with this, the support of various technologies is needed: to produce raw materials without endangering the sustainability of natural resources, to process raw materials efficiently (zero waste), to provide alternative energy substitution of fossil energy, to provide alternative auxiliary materials, and to deal with industrial waste (Ramdhani, Aulawi, Ikhwana, \& Mauluddin, 2017). Technology innovation based on nanotechnology and biotechnology will be a part that can accelerate the realization of the green industry concept. In addition, wise steps are needed to maintain the balance of natural resources by carrying out environmental management.

The development of the green industry in Indonesia is growing. Several things drive this situation. Firstly, the increase in company motivation to participate in the transformation process to be the green industry, which minimizing the negative impacts of their activities. Thus the company is increasingly concerned with the environment and sustainability issues. This is considered as a distinguishing and innovative factor that provides competitive advantages for companies (Leipziger, 2016; Fraj-Andrés, Martinez-Salinas, \& Matute-Vallejo, 2009). In addition, organizations would incorporate these concerns in their processes, adopting green management policies, and including green marketing strategies in order to remain competitive (Straughan \& Roberts, 1999; Rivera-Camino, 2007).

Secondly, it is the community's encouragement reflected in increasing public awareness of the environment. It can be seen from consumer behavior, which is moving to greener products. According to Afonso, Gavilan, GarcíaMadariaga, and Gonçalves (2018) increasing environmental awareness had a significant role in purchasing behavior, with more consumers considering the environmental impact of their buying decisions and looking for greener products for their purchasing options.

In addition to the community's encouragement, the government also gave support through the Ministry of Industry. The Ministry of Industry is very instrumental in encouraging the green industry in Indonesia. One effort is by awarding the green industry award since 2010. In 2018, 143 companies were awarded as green companies. These companies certainly have a strategic priority in carrying out their business.

Based on the description of the conditions and challenges mentioned above, it is necessary to research to find out what strategic priorities green 
companies need to have in Indonesia. These priorities are essential in the face of the disruption era. Using a unique technique of Wordle, we characterized keywords in the company profiles, contributing to the green activities. This means will allow capturing the vital message of being sustainable firms.

\section{THEORETICAL REVIEW}

Strategic Priorities

Strategic priority is a collection of ideas and strategies that are a top priority in the company (Lidow, 2017). In each step of determining priorities, the strategic management group ranks the ideas produced at each stage of the process. Preferences arranged in an achievement index combine rankings made by applying several criteria. Strategic priorities are very significant for companies or institutions because they can affect the company's performance. Tarigan (2005) found that the company's vital priority row had a positive effect on company performance. This result is also in line with the research of Verbeeten and Boons (2009), who found that strategic priorities had a positive effect on company performance.

\section{Green Industry}

The green industry is an industry that focuses on the implementation of efficiency and effectiveness in the production process by using sustainable resources (Lentera Bisnis, 2018). It can be said that the green industry is environmentally friendly. There are nine types of green industries, including:

1. development of energy forests,

2. ecotourism,

3. establishment of botanical gardens or urban jungles,

4. captive wild and rare animals,

5. development of non-timber forest products such as sap and so on,

6. development of imported substitution products,

7. processing energy waste from the results of microbial utilization,

8. geothermal utilization,

9. ecosystem restoration.

Meanwhile, the Ministry of Industry has issued a regulation concerning guidelines for the preparation of green industry standards as stipulated in the Minister of Industry Regulation Number 51 / M-IND / PER / 6/2015. The Green Industry Standard is a reference for industry players in consensus building related to raw and auxiliary materials, energy, production processes, products, business management, waste management system, and other aspects that aim to realize a green industry.

\section{METHODOLOGY}

Population and Sample

The population of this research is the companies that awarded as green companies by the Ministry of Industry. In 2018, 143 companies were awarded as 
green companies. The sample of this research is 87 companies in level 5. Level 5 is the highest level of green companies according to the indicators.

\section{Research Type}

This type of research is exploratory research, namely research that aims to explore a variety of information, is explaining and exploring ideas (Solimun \& Fernandes, 2017). The research method used in this study is qualitative clustering through idea networking.

\section{Idea Networking}

The research method used in this study is qualitative clustering through idea networking. Idea networking is part of concept mapping (Metcalfe, 2007), which classifies, connects, and group ideas. The source of the idea statement can be relevant to the problem situation. This statement can be "interview transcripts, community meetings, memorized comments from a conversation or statement in company documents" (Metcalfe, 2007). In this method, statements of ideas are extracted and linked to each other to produce diagrams and produce a collection of reports that can be generalized to priority.

After finding these priorities, the researcher conducted a rational analysis to explore the tension or interrelationship between priorities as an illustration of creative strategies (Metcalfe, 2014). There are no best or most important priorities, but the different generations of concepts can encourage balance and creativity. The author analyzes the dialectics and the potential tension between priorities.

Concept mapping can apply to various problems, especially excavation of ideas and networking ideas (idea networking). Some studies use this method in solving the problem, for example, the Borg (2010) study that found strategic priorities in the construction industry in Australia and research by Ridloah (2016), who found strategic priorities of banking industries in Indonesia.

\section{Data Analysis}

To conceptualize the strategic priorities of green companies in Indonesia, researchers link the institution's mission statement, which is available on the company's website. This network provides a qualitative means for grouping statements inductively (Hassanli \& Metcalfe, 2013). The mission statement is chosen because it reveals the strategy action in question, supported by the company leader and available to the public. An example of a mission statement is producing and trading cement that is oriented to customer satisfaction using environmentally friendly technology' (www.semengresik.com).

These statements are arranged and numbered, then linked to the use of keywords. The link is recorded in the social network analysis program called Wordle. Some social network analysis programs can be used, such as NodeXL, UCINET, and Gephi, each with very similar grouping algorithms. Wordle is used in this study because they are relatively easy to operate and support Microsoft.

\section{RESULTS}

The sample of this research is 87 companies that were awarded as the best green companies in level 5 . We collected vision and mission statements from the 
companies' website. This process was networking ideas. Then, the links were recorded in the wordle program to produce keywords of collection statements.

Based on the results of networking ideas, there are some strategic priorities for green companies in Indonesia (figure 1). The strategic priorities are Excellence, Sustainability, Eco-friendly, CSR, Value Creation, Customer Focus, Efficient. The authors choose these seven strategic priorities because these priorities are the most important or most often appear in the company's vision and mission documents that we examine. The more important a strategic priority, the greater the font size (see figure 1).

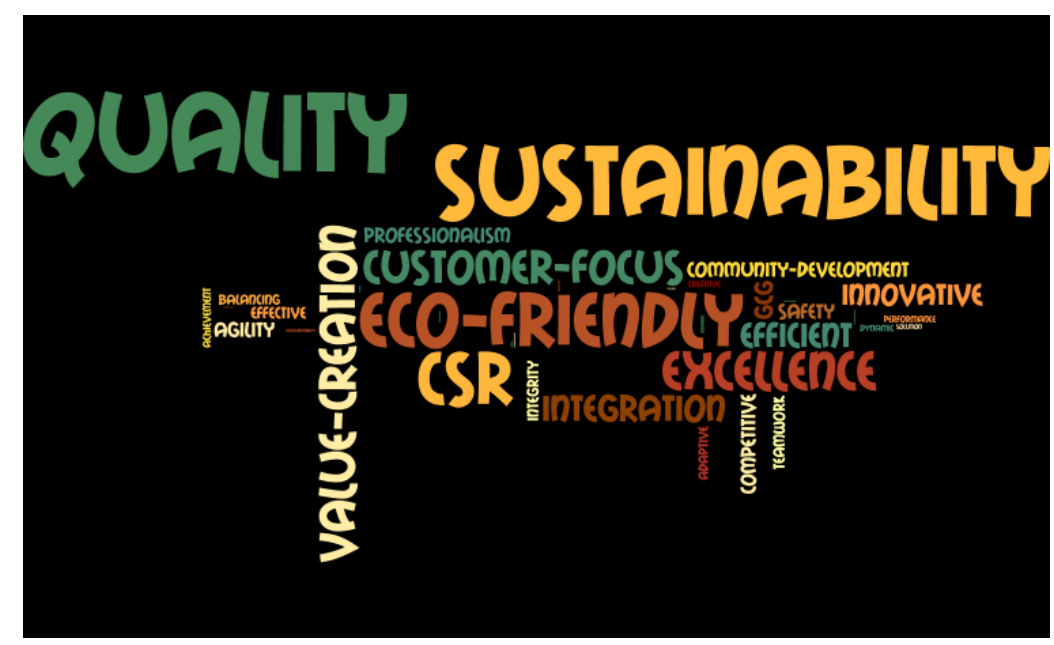

Figure 1. Result of Idea Networking

\section{DISCUSSION}

Excellence

Excellence can mean always showing passion for excellence and trying to work hard for maximum results. In an organization, this excellence covers various fields such as operational excellence, service excellence, leadership excellence, etc. Excellence is related to quality. In the US, business excellence and Total Quality Management (TQM)are interchangeable. However, in Europe, business excellence is different from TQM. It is considered to be beyond Total Quality Management (Oakland \& Tanner, 2008). Based on the results of Oakland and Tanner (2008) research, business excellence has a positive effect on company performance. A statement from this cluster is: always innovating, focusing on customer needs, offering superior brands with unmatched performance (Indofood, 2019). Establish operational excellence capabilities through continuous improvement and innovation with good corporate governance (PTPN10, 2019).

\section{Sustainability}

Sustainability is the ability to exist continually. There are four pillars of sustainability indicators, including environmental, social, economic, and governance indicators. Based on the findings of Whitehead (2017) that it is found that environmental issues have the highest priority issues, followed by social issues related primarily to worker wellbeing. Moore et al. (2017) fostered an 
inclusive definition of sustainability that includes five constructs that include: (1) the period of time, (2) continuity of the program, clinical intervention, and/or implementation strategies (3) maintaining individual behavior change; (4) the program and individual behavior change may evolve while (5) continuing to produce benefits for individuals/systems. An example of mission statements from this cluster is: providing solutions for all needs related to natural rubber in a sustainable manner (Kirana Prima, 2019).

\section{Eco-friendly}

Eco-friendly is one of the strategic priorities of green companies in Indonesia. Eco-friendly or environmentally friendly literally means not harmful to the environment. Eco-friendly has a positive effect on the company's performance. Research by Leonidou et al. (2016) found that the effect of eco-friendly orientation on performance has become stronger when it has adequate resources and capabilities to green initiatives. The example of the mission statement of this cluster is to carry out all company activities that are environmentally sound (PTPNIII, 2019).

\section{CSR}

CSR or Corporate Social Responsibility means treating stakeholders ethically or in a responsible manner (Wan-Jan 2006; Dahlsrud 2008). According to Falkenberg and Brunsael (2011), CSR is a real strategic necessity, not only as a potential competitive advantage for companies. Some studies found that CSR can be as research by Story and Neves (2014) and Kao et al. (2018). An example of the mission statement of this cluster is to expand employment to improve people's welfare in general and improve the standard of living of farmers and employees in particular (PTPNIII, 2019).

\section{Value Creation}

The value creation is essential for strategic success. Value creation is a performance of actions that increases the value of goods, services, or even a business (business dictionary.com). The firms can focus on value creation both in terms of creating better value for customers as well as for shareholders and other stakeholders. Companies can create value through stakeholder's synergy (Tantalo \& Priem, 2014) and social strategies (Husted, 2015). An example of the mission statement of this cluster is creating value through modern technology (ALP Petro Industry, 2019).

\section{Customer Focus}

Customer focus is one of the strategic priorities of green companies in Indonesia. Customer focus means that companies use existing resources quickly and flexibly to meet customer needs and expectations. Various studies related to the importance of customer focus in inter-organizational settings are Rindfleisch and Moorman (2003); Saparito et al. (2004); Wuyts et al. (2015). Wuyts et al. (2015) stated that firms with steady customers focus on having strongly-held standardized processes and procedures directed toward understanding customers and fulfilling their needs. With the presence of customer focus, customer 
satisfaction is to increase. An example of the mission statement of this cluster is that we guarantee customer satisfaction by prioritizing excellent service (Indomilk, 2019).

\section{Efficient}

Efficient is one of the strategic priorities for the green industry in Indonesia. Efficient means doing work using resources properly without waste. Concerning green companies, efficiency is more specific to eco-efficiency. According to Huppes and Ishikawa (2005), eco-efficiency analysis is based on the concept of creating more goods and services while producing less waste and pollution. An example of the mission statement of this cluster is to build a sustainable plantation and downstream industries that are environmentally friendly on appropriate technology, so that maximum production, good quality, efficient costs and increasing value-added are obtained. (PTPNIII, 2019).

\section{FURTHER STUDY}

This study aimed to provide valuable information for green companies in facing challenges in the era of disruption. Besides, the results of this study can be a preliminary study to conduct further research on green industries' strategic priorities. This study only used qualitative data from the mission statements of green companies in Indonesia. Therefore, we suggested new research to combine the data with a primary source such as from focus group discussion or depth interviews with stakeholders for adding some more novel insight.

\section{REFERENCES}

Afonso, C., Gavilan, D., García-Madariaga, J., \& Gonçalves, H. M. (2018). Green consumer segmentation: managerial and environmental implications from the perspective of business strategies and practices. In Sustainability in Innovation and Entrepreneurship (pp. 137-151). Springer, Cham.

ALP Petro Industry. (2019). http://alppetro.co.id/id/about

Borg, A. (2010). Concept Mapping as an Alternative Approach to Using Business Models for the Analysis of the Commercial Construction Industry in Australia. The University Of South Australia.

Dahlsrud, A. (2008). How corporate social responsibility is defined: an analysis of 37 definitions. Corporate social responsibility and environmental management, 15(1): 1-13.

Falkenberg, J., and Brunsael, P. (2011). Corporate social responsibility: a strategic advantage or a strategic necessity?. Journal of Business Ethics, 99(1): 9-16.

Fraj-Andrés, E., Martinez-Salinas, E., \& Matute-Vallejo, J. (2009). A multidimensional approach to the influence of environmental marketing 
and orientation on the firm's organizational performance. Journal of Business Ethics, 88(2), 263-286.

Hassanli, N, \& Metcalfe, M. (2013). 'Idea networking: constructing a pragmatic conceptual frame for action research interventions.' Systemic Practice and Action Research, 1-13.

Huppes. G. \& Ishikawa, M. (2005). Eco-efficiency and its terminology. J Ind Ecol 9: 43-46.

Husted, B. W., Allen, D. B., \& Kock, N. (2015). Value creation through social strategy. Business $\mathcal{E}$ Society, 54(2): 147-186.

http://www.businessdictionary.com/definition/value-creation.html

http://www.semengresik.com/visimisi/

Indofood. (2019). https://www.indofood.com/company/vision-mision-values

Indomilk. (2019).http:// www.indomilk.com/Tentang

Kao, E. H., Yeh, C. C., Wang, L. H., \& Fung, H. G. (2018). The relationship between CSR and performance: Evidence in China. Pacific-Basin Finance Journal, 51: 155-170.

Kirana Prima. (2019). https://gapkindo.org/cabang/95-west-kalimantan/345pt-kirana-prima.

Leipziger, D. (2016). The corporate responsibility code book (3rd ed.). Greenleaf Publishing Limited.

Lentera Bisnis. (2018). Pengertian Industri Hijau. Available at: https://www.lenterabisnis.com/pengertian-industri-hijau. 12 December 2018.

Leonidou, L. C., Christodoulides, P., \& Thwaites, D. (2016). External determinants and financial outcomes of an eco-friendly orientation in smaller manufacturing firms. Journal of Small Business Management, 54(1): $5-25$.

Lidow, D. (2017). A Better Way to Set Strategic Priorities. Harvard Business Review. Available at: https://hbr.org/2017/02/a-better-way-to-set-strategicpriorities.

Metcalfe, M. (2007). 'Problem conceptualization using idea networks.' Systemic Practice and Action Research. 20 (2): 141-150

Metcalfe, M. (2014). Strategic Concepts Book of Readings. University of South Australia, Adelaide.

Moore, J. E., Mascarenhas, A., Bain, J., \& Straus, S. E. (2017). Developing a comprehensive definition of sustainability. Implementation Science, 12(1): 110. 
Oakland, J. S., \& Tanner, S. J. (2008). The relationship between business excellence and performance-An empirical study using Kanji's leadership excellence model. Total Quality Management, 19(7-8): 733-749.

PTPNIII. (2019). http://www.ptpn3.co.id/visi_misi.php?h=tentang-kami

PTPN10. (2019). http://ptpn10.co.id/page/profil\#visimisi

Ramdhani, M. A., Aulawi, H., Ikhwana, A., \& Mauluddin, Y. (2017). Model of green technology adaptation in small and medium-sized tannery industry. Journal of Engineering and Applied Sciences, 12(4), 954-962.

Ridloah, S. (2016). A Qualitative Analysis Into The Strategic Priorities of The Indonesian Bank Industry. Jurnal Dinamika Manajemen. 7(1): 91-105.

Rindfleisch, A., Moorman, C. (2003). Interfirm cooperation and customer orientation. Journal of Marketing Research, 40 (November), 421-436.

Rivera-Camino, J. (2007). Re-evaluating green marketing strategy: a stakeholder perspective. European journal of marketing.

Saparito, P.A., Chen, C.C., Sapienza, H.J. (2004). The role of relational trust in bank-small firm relationships. Academy of Management Journal, 47(3): 400410.

Solimun \& Fernandes, A. A. R. (2017). Novelty Penelitian. Disampaikan dalam Workshop Publikasi Jurnal Internasiona Scopus. Semarang, 25-26 November 2017.

Story, J., \& Neves, P. (2015). When corporate social responsibility (CSR) increases performance: exploring the role of intrinsic and extrinsic CSR attribution. Business Ethics: A European Review, 24(2), 111-124.

Straughan, R. D., \& Roberts, J. A. (1999). Environmental segmentation alternatives: a look at green consumer behavior in the new millennium. Journal of consumer marketing.

Tantalo, C., \& Priem, R. L. (2016). Value creation through stakeholder synergy. Strategic Management Journal, 37(2): 314-329.

Tarigan, R. (2005). An Evaluation of the Relationship between Alignment of Strategic Priorities and Manufacturing Performance. International Journal of Management. 22(4): 586.

The

Ministry

of

Industry.

(2014).

http://www.kemenperin.go.id/artikel/8442/Seminar-Nasional-

Teknologi-Industri-Hijau-2014:-Litbangyasa-Untuk-MendukungRealisasi-Industri-Hijau

Verbeeten, F. H., \& Boons, A. N. (2009). Strategic priorities, performance measures, and performance: an empirical analysis in Dutch firms. European Management Journal, 27(2): 113-128. 
Wan-Jan, W. S. (2006). Defining Corporate Social Responsibility. Journal of Public Affairs, 6: 177-184.

Whitehead, J. (2017). Prioritizing sustainability indicators: Using materiality analysis to guide sustainability assessment and strategy. Business Strategy and the Environment, 26(3): 399-412.

Wuyts, S., Rindfleisch, A., \& Citrin, A. (2015). Outsourcing customer support: The role of provider customer focus. Journal of Operations Management, 35: 4055 . 